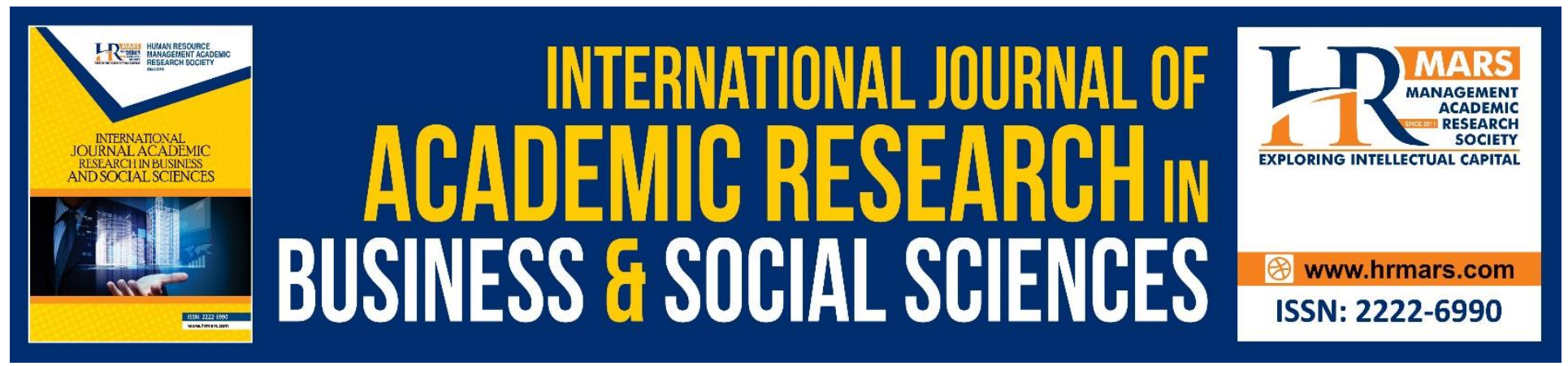

\title{
Stock Market Performance, Foreign Direct Investment and Economic Growth in Nigeria after the introduction of Structural Adjustment Programme
}

\section{Gilbert Deinde Ifarajimi}

To Link this Article: http://dx.doi.org/10.6007/IJARBSS/v8-i12/5385

DOI: $10.6007 /$ IJARBSS/v8-i12/5385

Received: 24 Nov 2018, Revised: 26 Dec 2018, Accepted: 29 Dec 2018

Published Online: 30 Dec 2018

In-Text Citation: (Ifarajimi, 2018)

To Cite this Article: Ifarajimi, G. D. (2018). Stock Market Performance, Foreign Direct Investment and Economic Growth in Nigeria after the introduction of Structural Adjustment Programme. International Journal of Academic Research in Business and Social Sciences, 8(12), 2044-2058.

Copyright: (C) 2018 The Author(s)

Published by Human Resource Management Academic Research Society (www.hrmars.com) This article is published under the Creative Commons Attribution (CC BY 4.0) license. Anyone may reproduce, distribute, translate and create derivative works of this article (for both commercial and non-commercial purposes), subject to full attribution to the original publication and authors. The full terms of this license may be seen at: http://creativecommons.org/licences/by/4.0/legalcode

Vol. 8, No. 12, 2018, Pg. 2044 - 2058

Full Terms \& Conditions of access and use can be found at http://hrmars.com/index.php/pages/detail/publication-ethics 


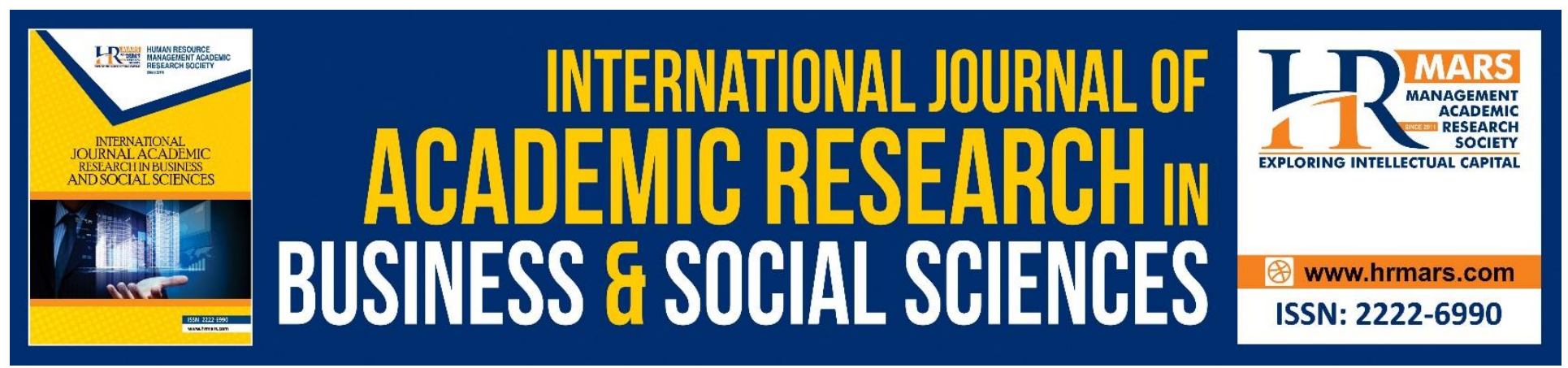

\title{
Stock Market Performance, Foreign Direct Investment and Economic Growth in Nigeria after the introduction of Structural Adjustment Programme
}

\author{
Gilbert Deinde Ifarajimi, Ph.D., FCA \\ Department of Economics, Caleb University, Imota, Lagos State \\ Email: bursdare@gmail.com
}

\begin{abstract}
The study examined stock market performance, foreign direct investment and economic growth in Nigeria after the introduction of the Structural Adjustment Programme. Annual time series data over the period of 31 years (1986 to 2016) and Johansen Co-integration technique were used. Granger causality test was also employed to determine the direction of causality between stock market performance, foreign direct investment and economic growth in Nigeria. The results suggest that there is long-term co-integration among economic growth, foreign direct investment (FDI), stock market development and inflation. The long-term elasticity estimates of the stock market performance showed expected sign and was statistically significant. In the short-run, stock market has significant positive relation to economic growth. The impact of FDI on growth is also significant and positive. The results also indicate that the negative impact of inflation on economic growth is statistically significant. The empirical findings of the study reveal that stock market development and FDI inflows play vital roles in the process of economic growth in Nigeria. Result of the OLS technique indicates that FDI had positive but insignificant impact on economic growth in Nigeria during the period. Available records showed that the substantial inflow of FDI into Nigeria during the period of study did not yield the expected result of rapid economic growth due to over-concentration of FDI on the oil and gas sector.
\end{abstract}

Keywords: Economic Growth, Foreign Direct Investment, Inflation, Stock Market Development.

\section{Introduction}

In 1986, Nigeria embraced the Structural Adjustment Programme which was recommended by the International Monetary Fund and the World Bank. The Structural Adjustment Programme (SAP) influenced the economic policies of the country and led to economic and financial reforms in the late 1980 s and early 1990s. The programme was proposed as an economic package to rapidly and effectively transform the Nigerian economy within two years (Yesufu 1996). However, until SAP was 
INTERNATIONAL JOURNAL OF ACADEMIC RESEARCH IN BUSINESS AND SOCIAL SCIENCES Vol. 8, No. 12, Dec, 2018, E-ISSN: 2222-6990 @ 2018 HRMARS

abandoned in 1994, the objectives were not achieved due to the inability of government to judiciously implement some of its policy measures (Oyefusi and Mogbolu 2003). Among the prescriptions of SAP were liberalization of the Nigerian Capital Market and exchange rate in order to encourage the inflow of foreign direct investment (FDI) to foster rapid economic growth. According to Soyode (1990) and Alile (1996), the introduction of SAP in Nigeria has resulted in a very significant growth of the country's stock market as a result of deregulation of the financial sector and the privatization exercise which exposed investors and companies to the significance of the stock market. The primary measure to assess the expansion of a stock market is to look at changes in its dimension (Okonkwo, Oguru \& Ajudua, 2014). Notable measures of stock market performance include All Share Index (ASI), Market capitalisation and volume traded. The All Share Index which was only 163.8 basis points in 1986 when SAP was introduced rose to 6,440 51 basis points in 1996 and reached an all time high of 63,500 basis points in 2009 before the global market crises. At the end of 2016, the ASI stood at 26,223 basis points, showing exponential increase above the 163.8 basis points of 1986. Similarly, Market capitalisation which was only 6.8 billion naira in 1986 rose rapidly (after the introduction of SAP) to 285 billion naira in 1996 and stood at over 16 trillion naira at the end of 2016. Ariyo and Adelegan (2005) agreed that the liberalization of capital market led to the growth of the Nigerian capital market but its impact at the macroeconomic level was negligible.

Some of the notable reforms following the introduction of SAP include monetary and fiscal policies, sectoral reforms such as removal of oil subsidy in 1988 to the tune of $80 \%$, interest deregulation from August 1987, financial market reform and public sector reforms which led to the full or partial privatization and commercialization of about 111 public owned enterprises. The Nigerian Stock Exchange also played significant roles during the offer for sale of the shares of the affected enterprises (World bank 1994; Anyanwu, 1997; Oyefusi and Mogbolu, 2003). Again the capital market was instrumental to the emergence of 25 banks that were able to meet the minimum capital requirement of $\mathrm{N} 25$ billion during the banking sector consolidation in 2005 . The stock market has helped government and corporate entities to raise long term capital for financing new projects and expanding industrial/ commercial concerns (Nwankwo 1991) .

A well-established stock market is generally believed to be an indicator of impressive macroeconomic performance of a country (Azam, Haseeb, Samsi and Raji, 2016). The capital market is expected to channel capital or long-term resources to firms with relatively high and increasing productivity and thus enhance economic expansion and growth (Alile 1996). Caporale, Howells, and Soliman, (2004) argued that active stock markets perform a decisive role in assigning investment to the corporate sector. The stock market plays a pivotal role in the development of commerce and industry and as a result, it affects the growth of the economy. It is assumed that the existence of active and stable stock market can stimulate the rate of economic growth, but how stable has the stock market been in Nigeria after liberalization of the capital market and exchange rate as prescribed by SAP. Three decades after the introduction of SAP, there seems to be tremendous improvement in the overall performance of the Nigerian stock market but how well has this impacted on the growth of the Nigerian economy?

Similarly, increasing foreign direct investment (FDI) is expected to impact positively on economic growth of the recipient country (Azam \& Ibrahim, 2014). After the introduction of SAP in Nigeria in 1986, there has been tremendous inflow of (FDI) into the country. Specifically, Foreign Direct 
Investment which was only 736 billion naira in 1986 rose to 111,275 billion naira in 1996 and had increased significantly to 959,520 billion naira in 2016. Unfortunately, most of the inflow of FDI was concentrated on the oil and gas sector, leading to stunted growth of the economy and exacerbating its mono-product nature (Ifarajimi and Ola, 2018).

Ekundayo (2002) argued that a nation requires a lot of local and foreign investments to attain sustainable economic growth and development. It is apt to find out how sustainable has been the growth of Nigerian economy following the massive inflow of FDI into the nation after the introduction of SAP..

The effect of the stock market on economic growth is so far a debatable issue as many prior studies have explained stock market from different perspectives. The objective of this study is to examine stock market performance, the inflow of foreign direct investment and economic growth in Nigeria after the introduction of SAP. The study covers a period of 31 years (1986-2016).

For empirical analysis, time series cross country data over the period 1986 to 2016 were used. The study investigates whether stock market performance and the inflow of FDI play paramount role in promoting economic growth of Nigeria in spite of rising inflation. The causal relationship among stock market growth, FDI and economic growth was also examined. This study is distinguished from the other studies in term of time period, the set of variables and the policy framework. The outcomes of the study are expected to serve as guide to decision makers in formulating policies that may promote efficient performance of the stock market and properly direct the inflow of FDI to enhance higher level of sustainable economic growth in Nigeria. Empirical studies on the impact of stock market performance and FDI on economic growth in Nigeria appear to be rare. Therefore, this study will contribute and enrich the literature in this regard.

The remainder of this study is organized as follows: Section 2 provides the literature review which incorporates the theoretical and empirical review while section 3 describes the methodology, consisting of model specification, sources of data and method of analysis. Section 4 reports the empirical results, while section 5 provides the conclusion and recommendations arising from the study.

\section{Literature Review}

Several prior studies have examined the connection between stock market development and economic growth, yet, they have not reached conclusion as their results remain mostly contradictory. The general observation from the review of previous studies is that the connection between stock market development and economic growth is either positive or negative and in some cases, no relationship at all.

Atje and Jovanovic (1993) employed a data set for 39 countries and found statistically significant positive relationship between stock markets growth and economic growth for the period 1980-1988. It is believed that a well-functioning stock market contributes to total productivity, and developed financial markets are considered to be important component of long-run economic growth (Levine, Loayza, and Beck, 2000; Husain, 2006; Barna and Mura, 2010; Cooray, 2010; Kolapo and Adaramola, 2012 and Shin, 2013). It is therefore expected that every stable stock market will expedite the convenience of long-term capital for cost-effective activities of production which is required for the 
process of economic growth and development. This is also considered a pre-requisite to sustainable economic growth that makes the national economy to attract more foreign investors.

In the case of sub-Saharan Africa, Enisan and Olufisayo (2009) observed that the stock market development and economic growth has a significant positive long-run relationship during the period 1980-2004. For Egypt and South Africa, the stock market is co-integrated with economic growth and the Granger causality test indicates that stock market Granger causes economic growth. Other results of granger causality tests suggest a bidirectional link between stock market and economic growth for Cote D'Ivoire, Kenya, Morocco and Zimbabwe. However, in the case of Nigeria, weak evidence is observed for the relationship between these variables.

Balago (2014) found that total market capitalization and foreign direct investment (FDI) have positive impact on economic growth in Nigeria during 1990-2009. In another study, Nguyen and Pham (2014) found causality between stock market development and economic growth in Canada but it is not the case in Australia during 1981 to 2012. In the case of Canada, the findings suggested that stock market development and economic growth have long-run linkage and that the stock market development boosts economic growth. In the case of Ghana, Osei (2006) demonstrated, that the stock market performance Granger-causes economic growth.

For the study of 42 emerging markets during 1995-2006, Masoud and Hardaker (2012) found that the stock market development has a significant positive impact on economic growth. Miguel, Fuinhas, and Marques (2013) reported bidirectional causality between the stock market and economic growth in Portugal for the period 1993-2011.

On the other hand, numerous studies have found insignificant or weak negative relationship between the stock market development and economic growth. For example, Harris (1997) re-examined the correlation between stock markets and economic growth on the data earlier used by Atje and Jovanovic (1993), but found no proof that the level of stock market determines the growth of per capita output. The results of Ram (1999) revealed that there is insignificant or weak negative relationship between stock market development and real per capita growth rate for 95 countries. The study claimed that contrary to the conclusions reached in many prior studies, the empirical result did not favour the view that stock market development encourages economic growth.

According to Sarkar (2007), there is no relationship between stock market and economic growth.

Similarly, Okodua and Ewetan (2013) in their study," Stock Market Performance and Sustainable Economic Growth in Nigeria", using the autoregressive distributed lag estimation technique came to conclusion that the overall output in the Nigerian economy is less sensitive to changes in stock market capitalization.

From various earlier findings, the effect of FDI on the host economyhas been quite controversial and inconclusive. Aitken and Harrison (1999) in their study found a negative influence of FDI on productivity of domestic firms in manufacturing industry in Venezuela. This could happen through repatriation of profit and market stealing effect. Gorg and Greenwood (2002) conclude that the effect of spillovers from foreign-owned to domestically owned firms are mostly negative. Also, Stanisic (2008) did not find any positive correlation between FDI inflows and economic growth.

On the contrary, Emmanuel (2016) examined the effect of foreign direct investment on economic growth in Nigeria from1981 to 2015 using secondary data and employed multiple regression 
INTERNATIONAL JOURNAL OF ACADEMIC RESEARCH IN BUSINESS AND SOCIAL SCIENCES

Vol. 8, No. 12, Dec, 2018, E-ISSN: 2222-6990 @ 2018 HRMARS

technique for its analysis. The results showed that foreign direct investment has a positive and significant effect on economic growth in Nigeria

\section{Model Specification}

In order to verify the linkage among economic growth, stock market performance, inflation rate and incoming FDI variables, the following model is used.

$Y t=\alpha 0+\alpha 1 S M C t+\alpha 2 I N F t+\alpha 3 F D I t+\varepsilon t$

Where, $Y$ represents the GDP per capita, SMC stands for market capitalization, INF denotes inflation, $F D I$ stands for foreign direct investment, and $\varepsilon t$ is the error term.

Theoretically, it is expected that the regression coefficient $\alpha 1$ will be positive implying that stock market development contributes to economic growth. Inflation as a macroeconomic variable has been included in the model since high inflation is believed to indicate macroeconomic instability of a country. Consequently, inflation negatively affects economic growth and thus, the sign of coefficient $\alpha 2$ is expected to be negative. FDI contributes to the economy in several ways such as increased competition due to access to bigger markets with variety of products, creating job opportunities and increasing government revenue. Therefore, the sign of the coefficient $\alpha 3$ is expected to be positive.

\section{Descriptive Statistics}

The table below shows the descriptive statistics for the series.

Table 4.1: Descriptive Statistics

\begin{tabular}{|lccccc|}
\hline Statistics & GDPGR & LOGFDI & LOGMC & LOGTSL & INF \\
\hline Mean & 5.072957 & 11.59596 & 6.399650 & 5.577454 & 20.69931 \\
Median & 5.487793 & 11.72756 & 6.496021 & 5.575949 & 12.17000 \\
Maximum & 14.60438 & 14.12322 & 9.856261 & 5.736572 & 76.75887 \\
Minimum & -1.510000 & 6.601230 & 1.916923 & 5.455321 & 0.223606 \\
Std. Dev. & 3.827141 & 2.206648 & 2.681703 & 0.068264 & 19.44252 \\
Skewness & 0.361245 & -0.676749 & -0.262525 & 0.424329 & 1.574512 \\
Kurtosis & 2.706727 & 2.387138 & 1.677269 & 2.716383 & 4.248142 \\
Jarque-Bera & 0.785334 & 2.759445 & 2.616004 & 1.034184 & 14.82085 \\
Probability & 0.675254 & 0.251648 & 0.270360 & 0.596252 & 0.000605 \\
Sum & 157.2617 & 347.8788 & 198.3892 & 172.9011 & 641.6787 \\
Sum Sq. Dev. & 439.4102 & 141.2096 & 215.7459 & 0.139799 & 11340.35 \\
Observations & 31 & 31 & 31 & 31 & 31 \\
\hline
\end{tabular}

\section{Source: Author's Computation}

The values obtained for standard deviations showed that there is no evidence of extreme values in the series except for inflation rate. All the values in Table 41 are low except for inflation. The skewness has positive values except log of FDI and Stock Market Capitalisation. They are rightly skewed. It is only inflation rate that has value higher than 3 for Kurtosis. There is evidence of normal distribution in inflation rate as a result of the Kurtosis value. Other series are less than 3 . All the series except inflation rate are normally distributed in terms of values obtained from Jarque Bera Statistics. The pro- value of inflation from Jarque Bera Statistic is less than the 0.05 level of significance. Other series have pro- values for Jarque Bera Statistics greater than $5 \%$ level of significance. Since the skewness 
INTERNATIONAL JOURNAL OF ACADEMIC RESEARCH IN BUSINESS AND SOCIAL SCIENCES

Vol. 8, No. 12, Dec, 2018, E-ISSN: $2222-6990$ C 2018 HRMARS

value of inflation rate is greater than zero and the Kurtosis value is greater than 3 , there is strong reason to conclude that inflation rate is normally distributed. The statistics explained have shown that all the series are normally distributed.

\section{Unit Root Test}

The author adopted Augmented Dickey Fuller technique to test for the stationarity in the series. Table 4.2 shows the summary of the results obtained for each of the series and the conclusion on the series.

Table 4.2: Test of Unit Root with ADF

\begin{tabular}{lllll}
\hline Variables & Level/Difference & $\begin{array}{l}\text { Critical Value } \\
\text { (ADF) }\end{array}$ & ADF & $\begin{array}{l}\text { ORDER OF } \\
\text { INTEG. }\end{array}$ \\
\hline GDPGR & Level & -2.9640 & -2.8340 & \\
& First Diff. & -2.9678 & $--7.1444^{*}$ & $1(1)$ \\
LOGFDI & Level & -2.9678 & -2.3317 & \\
& First Diff. & -2.9719 & $-9.1040^{*}$ & $1(1)$ \\
LOGMC & Level & -2.9640 & -1.37004 & \\
& First Diff. & -2.9678 & $-4.2104^{*}$ & $1(1)$ \\
LOGTLS & Level & -2.9640 & -2.5056 & \\
& First Diff. & -2.9678 & $-5.8158^{*}$ & $1(1)$ \\
INF & Level & -2.9810 & -1.1137 & \\
& First Diff. & -2.9810 & $-4.6666^{*}$ & $1(1)$ \\
\hline
\end{tabular}

* indicates significance at $5 \%$ level.

\section{Source: Author's Computation}

Table 4.2 shows that all the series are stationary at first difference $5 \%$ significant level. This provides evidence to carry out co-integration test.

\section{Co-integration Test}

The researcher proceeds to co-integration test after confirming the stationarity of each series. The result was given in Table 4.3. Johansen co-integration technique is employed to check for the existence of the long run relationship among the series.

Table 4.3: Results of Co-integration Test

\begin{tabular}{lcccc}
\hline Null Hypothesis & $\begin{array}{l}\text { Alternative } \\
\text { Hypothesis }\end{array}$ & Statistics & Critical Values & P- Values \\
\hline \multicolumn{4}{l}{ Model I; SERIES: } & GDPGR, LOGFDI, LOGSM, LOGTSL, INF \\
$r=0$ & $r \geq 1$ & 115.7101 & 69.81889 & 0.0000 \\
$r \leq 1$ & $r \geq 2$ & 62.39546 & 47.85613 & 0.0012 \\
$r \leq 2$ & $r \geq 3$ & 24.99895 & 29.79707 & 0.1615 \\
$r \leq 3$ & $r \geq 4$ & 9.054461 & 15.49471 & 0.3604 \\
$r \leq 4$ & $r \geq 5$ & 2.762686 & 3.841466 & 0.0965 \\
\hline
\end{tabular}

Source: Author's Computation 
INTERNATIONAL JOURNAL OF ACADEMIC RESEARCH IN BUSINESS AND SOCIAL SCIENCES

Vol. 8, No. 12, Dec, 2018, E-ISSN: 2222-6990 @ 2018 HRMARS

Table 4.3 shows that there are two co-integrating equations for Trace test. This result shows that the series in each of the model is co-integrated and therefore they have an error correction representation. With this result, the author proceeds to long run and short run regression analysis.

\section{Long Run Regression}

The author first carried out the long run OLS before the short run analysis. In the long run estimation (See Appendix One), the value of Durbin Watson was 1.1199 which is less than 1.5 by the rule of thumb and this showed that there was serial correlation in the model. The author therefore adopted ARMA Maximum Likelihood method to correct the serial correlation. The result is presented in Table 4.4 below.

Table 4.4: Long Run Regression

\begin{tabular}{|l|l|l|l|}
\hline \multicolumn{2}{|l|}{ Dependent Variable: GDPGR } & & \\
\hline Method: ARMA Maximum Likelihood (OPG - BHHH) & \\
\hline Variable & Coefficient & t-Statistic & Prob. \\
\hline C & -125.1437 & -1.9819 & 0.0596 \\
\hline LOGFDI & -0.5642 & -0.3919 & 0.6987 \\
\hline LOGMC & 0.7116 & 0.5272 & 0.6031 \\
\hline LOGTLS & 23.8037 & 2.2153 & 0.0369 \\
\hline INF & -0.0210 & -0.5354 & 0.5975 \\
\hline AR(1) & 0.4625 & 1.9095 & 0.0687 \\
\hline R-squared & 0.4060 & \multicolumn{1}{|l|}{ Mean dependent } & 5.2924 \\
& & var & \\
\hline Adjusted R-squared & 0.2511 & S.D. dependent var & 3.6889 \\
\hline F-statistic & 2.6204 & Durbin-Watson stat & 1.8819 \\
\hline Prob(F-statistic) & 0.0438 & \\
\hline
\end{tabular}

\section{Source: Author's Computation}

The coefficient of determination $\left(\mathrm{R}^{2}\right)$ shows that the explanatory variables explained $40.6 \%$ of the total variation in Real Gross Domestic Product Growth Rate. The F-statistic showed that the model was statistically significant at $5 \%$ level of significance and the Durbin Watson statistic showed that the serial correlation has been corrected. The estimate of the constant is -125.14 implying that if all the independent variables are zero, Real Gross Domestic Product Growth Rate will approximately be reduced by $125.14 \%$. The coefficient for the FDI is -0.5642 . This implies that FDI has an indirect relationship with the Growth rate of Real Gross Domestic Product (GDPGR). This relationship is not statistically significant at the 0.05 level, as the pro value has shown. The stock market capitalisation on the other hand, is $0.7166 \%$. The sign of the coefficient implies that stock market capitalisation has an indirect relationship to the Growth rate of Gross Domestic Product (GDPGR). The relationship is not statistically significant at the 0.05 level, as the pro value has shown.

Total value of stock has a coefficient of 23.8037 indicating a direct relationship between Total value of stock and GDPGR. This conforms to a'priori expectation and is statistically significant as indicated by the pro value of 0.0369 . Inflation rate also has an indirect relationship with the GDPGR with a 
INTERNATIONAL JOURNAL OF ACADEMIC RESEARCH IN BUSINESS AND SOCIAL SCIENCES

Vol. 8, No. 12, Dec, 2018, E-ISSN: $2222-6990$ C 2018 HRMARS

coefficient of $0.021 \%$. This relationship agrees with a'priori expectation and is not significant as indicated by the probability value.

\section{Short Run Regression}

In the short run regression, none of the variables was significant and this necessitated the need to lag the variables and also carry out over-paremeterisation test. The Overperemeterised ECM is reported in Appendix Two to the study. The existence of variables that were not significant led the author to carry out Parsimonious ECM and its results are discussed below.

Table 4.5: Parsimonious ECM

Dependent Variable: D(GDPGR)

Method: Least Squares

\begin{tabular}{llcc} 
Variable & Coefficient & t-Statistic & Prob. \\
\hline C & -0.0867 & -0.1575 & 0.8760 \\
D(LOGTLS) & 31.9432 & 3.3865 & 0.0022 \\
ECM(-1) & -0.5014 & -2.8532 & 0.0082 \\
\hline R-squared & 0.4127 & Mean dependent var & -0.1137 \\
Adjusted R-squared & 0.3692 & S.D. dependent var & 3.7955 \\
F-statistic & 9.4858 & Durbin-Watson stat & 1.8289 \\
Prob(F-statistic) & 0.0007 & & \\
\hline
\end{tabular}

\section{Source: Author's computation}

The coefficient of ECM is -0.5014 with a pro value of 0.0007 . The ECM coefficient has the correct negative sign and it indicates a speed of adjustment of $50.14 \%$ which is statistically significant at the 0.05 level. This means that any disequilibrium in the system can be restored at a speed of adjustment of $50.14 \%$ which is considered to be very fast. The parsimonious ECM estimates shows that log of total value of stock is able to explain $41.27 \%$ of the total variation in the growth rate of Real GDP. The result shows that in the parsimonious ECM, log of total value of stock (D) LOGSTL) has a positive relationship with the Growth Rate of Real Gross Domestic Product D(GDPGR), with a coefficient of $31.94 \%$. This relationship conforms to a'priori expectation and it was also found to be statistically significant at the 0.05 level of significance. This finding shows that total value of stock promotes economic growth in the short run. A $1 \%$ change in total value of stock leads to $31.94 \%$ increase in real GDP growth rate.

\section{Conclusion}

The study examined the relationship between stock market performance, inflow of foreign direct investment and economic growth in Nigeria after the introduction of structural adjustment programme, using annual time series data over a period of 31 years from 1986 to 2016. In addition to the adoption of Johansen co-integration approach and OLS technique, granger causality test was also employed to determine the direction of causality between market performance, flow of FDI and economic growth. The findings show that both stock market performance and FDI inflows play vital 
roles in the process of economic growth in Nigeria during the period of study. The OLS result indicates that although FDI has positive impact on economic growth, the impact was insignificant as most of the inflow was directed to only the oil and gas sector. There was also a unidirectional causality between Total Listed Securities and FDI inflow. The study therefore recommends further reforms that would widen the coverage and improve the performance of the stock market to enhance sustainable economic growth. More companies should be encouraged to get listed on the stock exchange market to deepen the market. This can be done by reducing the listing fees and by providing more infrastructure (especially energy) to improve the ease of doing business in the country. Deliberate policies should also be formulated to spread the use of foreign direct investment among vital sectors of the economy. Particular attention should be paid to Agricultural, Manufacturing and Construction sectors in the utilization of FDI because of the value chain and positive externalities of these sectors in promoting rapid economic growth.

\section{Contributions to Knowledge}

This study empirically showed the positive impact of stock market performance and FDI on economic growth in Nigeria not-withstanding the negative effect of inflation. It also revealed that the utilization of FDI was highly skewed towards the oil and gas sector, thereby hampering even and sustainable growth. Earlier studies have considered the impact of stock market, FDI and inflation on economic growth separately, but this study has been able to provide holistic view on the variables in relation to economic growth. Contrary to widespread condemnation, the study showed that the Structural Adjustment Programme was a catalyst for economic growth of Nigeria during the period.

\section{References}

Alile H.I. (1996) The Stock Exchange and Capital formation in Nigeria. NIPSS, Kuru, Jos, Nigeria Anyanwu J.C (1998). Stock Market Development and Nigerian Economic Growth. Nigerian Financial Review, 7 (2): 6-13.

Ariyo A, and Adelegan O. ( 2005). Assessing the impact of Capital Market Reforms in Nigeria: An increment

Approach. Paper presented at the 46th annual conference of the Nigeria Economic Society in Lagos in August 2005.

Aitken, B. J. and Harrison, A. E. (1999). Do domestic firms benefit from Direct Foreign Investments? American Economic Review, 89 (3), 605-618.

Atje, R. and Jovanovic, B. (1993). Stock markets and development. European Economic Review, 37 (2), 632- 640.

Azam, M. and Ibrahim, Y. (2014). Foreign direct investment and Malaysia's stock market: Using ARDL bounds testing approach. Journal of Applied Economic Sciences, 4 (30), 591-601.

Azam, M., Haseeb, M., Samsi, A. B. and Raji, J. O. (2016). Stock market development and economic growth: Evidences from Asia-4 Countries. International Journal of Economics and Financial Issues, 6 (3), 1200-1208.

Azarmi, T., Lazar, D. and Jeyapaul, J. (2005), Is the Indian stock market a casino? Journal of Business and Economics Research, 3 (4), 63-72. 
INTERNATIONAL JOURNAL OF ACADEMIC RESEARCH IN BUSINESS AND SOCIAL SCIENCES

Vol. 8, No. 12, Dec, 2018, E-ISSN: 2222-6990 @ 2018 HRMARS

Balago, G.S. (2014), Financial sector development and economic growth in Nigeria: An empirical investigation. International Journal of Finance and Accounting, 3 (4), 253-265.

Barna, F. and Mura, P.O. (2010), Capital market development and economic growth: The case of Romania. Annals of the University of Petrosani, Economics, 10 (2), 31-42.

Caporale, G.M., Howells, P.G. and Soliman, A.M. (2004). Stock market development and economic growth: $\quad$ The causal linkage. Journal of Economic Development, 29 (1), 33-50.

Cooray, A. (2010). Do stock markets lead to economic growth? Journal of Policy Modeling, 32, 448-460.

Ekundayo, I.K. (2002). Creating a conducive Environment for Investment in the Nigerian Capital Market. Paper Presented at Public Enlightenment on Opportunities in the Capital Market for industrial Development of Kogi state ' Lokoja 29th March to1st April, 2002

Emmanuel I. J. (2016). Effect of foreign direct investment on economic growth in Nigeria. European Business \& Management. 2 (2), 40-46.

Enisan, A.A.and Olufisayo, A.O. (2009), Stock market development and economic growth: Evidence from seven Sub-Sahara African countries. Journal of Economics and Business, 61, 162-171.

Gorg and Greenwood (2002). Do domestic firms really benefit from FDI? Research Paper 2001/37, Globalisation and LABOUR Market Programme, at Leverhulme Centre for Researchand Economic Policy, Nottingham.

Harris, R.D.F. (1997), Stock markets and development: A re-assessment. European Economic Review, 41(1), 139-146.

Ifarajimi, G. D. and Ola, K. O. (2018). Impact of private investment on labour productivity in Nigeria. Journal of Economics and Applied Analysis, 3 (1), 19-31.

Kolapo, F. T, and Adaramola, A, O (2012). The Impact of the Nigerian Capital Market on Economic Growth (1990-2010). International Journal of Developing Societies, 1(1), 11-19

Levine, R., Loayza, N. and Beck, T. (2000). Financial intermediation and growth: Causality and causes. Journal of Monetary Economics, 46 (1), 31-77.

Masoud, N. and Hardaker, G. (2012). The impact of financial development on economic growth. Studies in Economics and Finance, 29(3), 148-173.

Miguel, M.L., Fuinhas, J.A. and Marques, A.C. (2013). Does the stock market cause economic growth? Portuguese evidence of economic regime change. Economic Modelling, 32, 316-324.

Nwankwo G.O. (1991) Money and capital market in Nigeria today. University of Lagos press, Lagos.

Okodua, H. and Ewetan, O. (2013). Stock market performance and sustainable economic growth in Nigeria: A bounds testing co-integration approach. Canadian Center of Science and Education, Journal of Sustainable Development; 6 (8). http://dx.doi.org/10.5539/jsd.v6n8p84

Okonkwo, O. N., Ogwuru, H. O and Ajudua, E. I. (2014). Stock market performance and economic growth in Nigeria: An empirical appraisal. European Journal of Business and Management, 6 (26), 33-43

Osei, K. A. (2006). Macroeconomic factors and the Ghana stock market. The African Finance Journal, $8(1), \quad 26-38$

Oyefusi S.A and Mogbolu R.O (2003). Nigeria and the Structural Adjustment programme. Benin City: Mindex Publishing. 387-402 
INTERNATIONAL JOURNAL OF ACADEMIC RESEARCH IN BUSINESS AND SOCIAL SCIENCES

Vol. 8, No. 12, Dec, 2018, E-ISSN: 2222-6990 @ 2018 HRMARS

Ram, R. (1999). Financial development and economic growth: Additional evidence. The Journal of Development Studies, 35 (4), 164-174.

Sarkar, P. (2007), Stock market development and capital accumulation: Does the law matter? A Case Study of India, MPRA Paper No. 5052.

Shin, Y. (2013). Financial markets: An engine for economic growth, The Regional Economist, Federal Reserve Bank of St. Louis, Central of America Economy.

Soyode, A. (1990). The role of capital in economic development. Security Market Journal 6

Stanisic, N. (2008). Do FDI increase economic growth of Southeastern European Transition economies? South-Eastern Europe Journal of Economics 1, 29-38.

Yesufu, T.M. 1996. The Nigerian economy: Growth without development. Ibadan: Kraft Books Limited.

World Bank. (2014), World Development Indicators. Washington, DC: The World Bank

\section{APPENDIX ONE \\ LONG RUN OLS}

Dependent Variable: GDPGR

Method: Least Squares

Date: 05/10/18 Time: 18:15

Sample (adjusted): 19862015

Included observations: 30 after adjustments

\begin{tabular}{lllll}
\hline \hline Variable & \multicolumn{2}{c}{ Coefficient Std. Error } & t-Statistic & Prob. \\
\hline \hline C & -90.84274 & 55.92208 & -1.624452 & 0.1168 \\
LOGFDI & -0.258385 & 1.315346 & -0.196438 & 0.8459 \\
LOGMC & 0.498159 & 1.120775 & 0.444477 & 0.6605 \\
LOGTSL & 17.33618 & 10.31055 & 1.681403 & 0.1051 \\
INF & -0.036799 & 0.038460 & -0.956835 & 0.3478 \\
\hline \hline R-squared & 0.253275 & & Mean dependent var & 5.292388 \\
Adjusted R-squared & 0.133799 & S.D. dependent var & 3.688895 \\
S.E. of regression & 3.433252 & Akaike info criterion & 5.455905 \\
Sum squared resid & 294.6804 & Schwarz criterion & 5.689437 \\
Log likelihood & -76.83857 & Hannan-Quinn criter. & 5.530614 \\
F-statistic & 2.119880 & Durbin-Watson stat & 1.119925 \\
Prob(F-statistic) & 0.108199 & & \\
\hline \hline
\end{tabular}

Long run OLS

Dependent Variable: GDPGR

Method: ARMA Maximum Likelihood (OPG - BHHH)

Date: 05/10/18 Time: 18:18

Sample: 19862015 
INTERNATIONAL JOURNAL OF ACADEMIC RESEARCH IN BUSINESS AND SOCIAL SCIENCES Vol. 8, No. 12, Dec, 2018, E-ISSN: 2222-6990 @ 2018 HRMARS

Included observations: 30

Convergence achieved after 22 iterations

Coefficient covariance computed using outer product of gradients

\begin{tabular}{lllll}
\hline \hline Variable & Coefficient Std. Error & t-Statistic & Prob. \\
\hline \hline C & -125.1437 & 63.14502 & -1.981846 & 0.0596 \\
LOGFDI & -0.564171 & 1.439500 & -0.391922 & 0.6987 \\
LOGMC & 0.711572 & 1.349849 & 0.527149 & 0.6031 \\
LOGTSL & 23.80371 & 10.74496 & 2.215338 & 0.0369 \\
INF & -0.021073 & 0.039361 & -0.535374 & 0.5975 \\
AR(1) & 0.462544 & 0.242230 & 1.909524 & 0.0687 \\
SIGMASQ & 7.813281 & 1.990479 & 3.925328 & 0.0007 \\
\hline \hline R-squared & 0.406030 & & Mean dependent var & 5.292388 \\
Adjusted R-squared & 0.251082 & S.D. dependent var & 3.688895 \\
S.E. of regression & 3.192372 & Akaike info criterion & 5.368393 \\
Sum squared resid & 234.3984 & Schwarz criterion & 5.695339 \\
Log likelihood & -73.52590 & Hannan-Quinn criter. & 5.472986 \\
F-statistic & 2.620421 & Durbin-Watson stat & 1.881866 \\
Prob(F-statistic) & 0.043832 & & & \\
\hline \hline
\end{tabular}

Inverted AR Roots

.46

\section{APPENDIX TWO}

\section{ECM MODEL}

Dependent Variable: D(GDPGR)

Method: Least Squares

Date: 05/10/18 Time: 18:35

Sample (adjusted): 19872015

Included observations: 29 after adjustments

\begin{tabular}{lllll}
\hline \hline Variable & \multicolumn{2}{c}{ Coefficient Std. Error } & t-Statistic & Prob. \\
\hline \hline C & 0.421757 & 0.755906 & 0.557949 & 0.5823 \\
D(LOGFDI) & -0.687623 & 0.991143 & -0.693767 & 0.4948 \\
D(LOGMC) & -0.845582 & 1.891507 & -0.447041 & 0.6590 \\
$D($ LOGTSL) & 29.53664 & 10.55204 & 2.799141 & 0.0102 \\
D(INF) & -0.023840 & 0.033828 & -0.704743 & 0.4880 \\
ECM(-1) & -0.536916 & 0.185157 & -2.899790 & 0.0081 \\
\hline \hline R-squared & 0.448383 & Mean dependent var & 0.030577 \\
Adjusted R-squared & 0.328467 & S.D. dependent var & 3.778098
\end{tabular}


INTERNATIONAL JOURNAL OF ACADEMIC RESEARCH IN BUSINESS AND SOCIAL SCIENCES Vol. 8, No. 12, Dec, 2018, E-ISSN: 2222-6990 @ 2018 HRMARS

\begin{tabular}{llll} 
S.E. of regression & 3.096043 & Akaike info criterion & 5.280118 \\
Sum squared resid & 220.4660 & Schwarz criterion & 5.563007 \\
Log likelihood & -70.56171 & Hannan-Quinn criter. & 5.368715 \\
F-statistic & 3.739126 & Durbin-Watson stat & 1.784316 \\
Prob(F-statistic) & 0.012676 & & \\
\hline \hline
\end{tabular}

Dependent Variable: D(GDPGR)

Method: Least Squares

Date: 05/10/18 Time: 18:37

Sample (adjusted): 19882015

Included observations: 28 after adjustments

\begin{tabular}{llllll}
\hline \hline Variable & Coefficient Std. Error & t-Statistic & Prob. \\
\hline \hline C & -0.554312 & 0.973657 & -0.569309 & 0.5762 \\
D(LOGFDI) & -0.091642 & 1.533640 & -0.059755 & 0.9530 \\
$D($ LOGMC) & -0.503939 & 1.951258 & -0.258263 & 0.7991 \\
$D($ LOGTSL) & 4.897245 & 16.09805 & 0.304214 & 0.7645 \\
D(INF) & -0.027327 & 0.034320 & -0.796241 & 0.4363 \\
D(LOGFDI(-1)) & 2.650735 & 1.479811 & 1.791265 & 0.0901 \\
D(LOGMC(-1)) & 0.734260 & 2.158897 & 0.340109 & 0.7377 \\
D(LOGTSL(-1)) & -8.792786 & 10.88083 & -0.808099 & 0.4296 \\
D(INF(-1)) & 0.055662 & 0.049550 & 1.123346 & 0.2761 \\
ECM(-1) & -0.478246 & 0.191312 & -2.499820 & 0.0223 \\
\hline \hline R-squared & 0.573387 & & Mean dependent var & 0.093434 \\
Adjusted R-squared & 0.360080 & S.D. dependent var & 3.831953 \\
S.E. of regression & 3.065371 & Akaike info criterion & 5.350667 \\
Sum squared resid & 169.1370 & Schwarz criterion & 5.826454 \\
Log likelihood & -64.90934 & Hannan-Quinn criter. & 5.496120 \\
F-statistic & 2.688087 & Durbin-Watson stat & 1.892603 \\
Prob(F-statistic) & 0.035435 & & \\
\hline \hline & & & & \\
\hline \hline
\end{tabular}

Dependent Variable: D(GDPGR)

Method: Least Squares

Date: 05/10/18 Time: 18:39

Sample (adjusted): 19872016

Included observations: 30 after adjustments

\begin{tabular}{|c|c|c|c|}
\hline Variable & Coefficient Std. Error & t-Statistic & Prob. \\
\hline C & -0.0866980 .550439 & -0.157507 & 0.8760 \\
\hline
\end{tabular}


INTERNATIONAL JOURNAL OF ACADEMIC RESEARCH IN BUSINESS AND SOCIAL SCIENCES Vol. 8, No. 12, Dec, 2018, E-ISSN: 2222-6990 @ 2018 HRMARS

\begin{tabular}{lllll} 
D(LOGTSL) & 31.94320 & 9.432510 & 3.386500 & 0.0022 \\
ECM(-1) & -0.501348 & 0.175712 & -2.853235 & 0.0082 \\
\hline \hline R-squared & 0.412682 & & Mean dependent var & -0.113655 \\
Adjusted R-squared & 0.369177 & & S.D. dependent var & 3.795511 \\
S.E. of regression & 3.014562 & & Akaike info criterion & 5.139426 \\
Sum squared resid & 245.3647 & Schwarz criterion & 5.279545 \\
Log likelihood & -74.09138 & Hannan-Quinn criter. & 5.184251 \\
F-statistic & 9.485827 & Durbin-Watson stat & 1.828890 \\
Prob(F-statistic) & 0.000758 & & \\
\hline \hline
\end{tabular}

